\title{
Compositional Imaging and Analysis of Late Iron Age Glass from the Broborg Vitrified Hillfort, Sweden
}

Edward P. Vicenzi ${ }^{1,3}$, Carolyn I. Pearce ${ }^{2}$, Jamie L. Weaver ${ }^{3}$, John S. McCloy ${ }^{4}$, Scott Wight ${ }^{3}$, Thomas Lam $^{1}$, Scott Whittaker ${ }^{5}$, Rolf Sjöblom ${ }^{6}$, David K. Peeler ${ }^{2}$, Michael J. Schweiger ${ }^{2}$, and Albert A. Kruger ${ }^{7}$

1. Museum Conservation Institute, Smithsonian Institution, Suitland, MD, USA

2. Pacific Northwest National Laboratory, Richland, WA, USA

3. National Institute of Standards and Technology, Gaithersburg, MD USA

4. School of Mechanical and Materials Engineering, Washington State University, Pullman, WA USA

5. National Museum of Natural History, Smithsonian Institution, Washington, DC, USA

6. Luleå University of Technology, Luleå, Sweden

7. Department of Energy, Office of River Protection, Richland, WA USA

Numerous Iron Age hillforts were constructed throughout Europe on high ground to serve ancient settlements [1]. The edifice walls of a small fraction of hillforts were vitrified as a result of high temperature activity, [2]. Swedish hillfort glasses from the Broborg Site near Uppsala, Sweden have recently been proposed as an analogue material to inform long term nuclear waste storage (Fig. 1A) [3]. As part of that effort, a fragment of the Broborg hillfort wall was embedded and polished prior to examination by $\mathrm{x}$-ray methodologies to determine its composition and microstructure (Fig. 1B).

A Bruker M4 Tornado with dual Bruker XFlash 6|60 detectors was used to collect hyperspectral micro$\mathrm{XRF}$ data with a $\mathrm{Rh}$ source and a $20 \mathrm{um}\left(\mathrm{Mo} \mathrm{K}_{\alpha}\right)$ polycapillary optic at two energies: 1) $25 \mathrm{keV} /$ no filter, and 2) $40 \mathrm{keV}$ with a $12.5 \mu \mathrm{m} \mathrm{Al}$ source filter [4]. An FEI Apreo scanning electron microscope (SEM) was used to collect an electron image montage spanning the specimen's polished surface, and electron beam-excited hyperspectral x-ray data was collected using dual Bruker XFlash 6|60 detectors at $15 \mathrm{keV}$.

Object-scale major element and electron imagery reveals the specimen is comprised of 3 principal chemical phases, an Fe-rich glass (dark), an Fe-poor glass rich in alkalis (milky), and quartz (Fig. 2A,E). Trace element imaging depicts unreacted zircon throughout the sample, $\mathrm{Zr}$ and $\mathrm{V}$ enrichment in the $\mathrm{Fe}-$ rich glass (Fig. 2B-C), and Rb enrichment in the Fe-poor glass (Fig. 2D). A more detailed view of the boundary between the 2 glass zones shows heavily embayed quartz, residual CaAl-silicate zones within the Fe-poor glass, FeMgAl spinel crystallization, and quench-crystallization in the Fe-rich glass (Fig, 3). Major element compositions of the glasses are broadly consistent with previous studies (Table 1) [4,5]. Importantly, the new trace element compositions of the glasses provide an opportunity to test a linkage with the bulk chemistry of lithologies found at Broborg to better understand the ancient melting processes via an elemental ratio comparison.

References:

[1] J McIntosh, Handbook to life in Prehistoric Europe. (Oxford University Press, 2009)

[2] FB Wadsworth et al. J Archaeol. Sci. 67 (2016), p. 7-13

[3] R Sjöblom, H Ecke, \& E Brännvall, Intl. J. Sust. Dev. Planning (2013).

[4] Any mention of commercial products is for information only; it does not imply recommendation or endorsement by NIST or DOE.

[5] P Kresten \& B Ambrosiani J. Swedish Antiquarian Res. 87 (1992)

[6] JL Weaver et al. Intl. J. Appl. Glass Sci. (in review) 
Figure 1. A) Oblique aerial view of the Broborg hillfort.

B) Sectioned hand specimen image of specimen from vitrified wall.
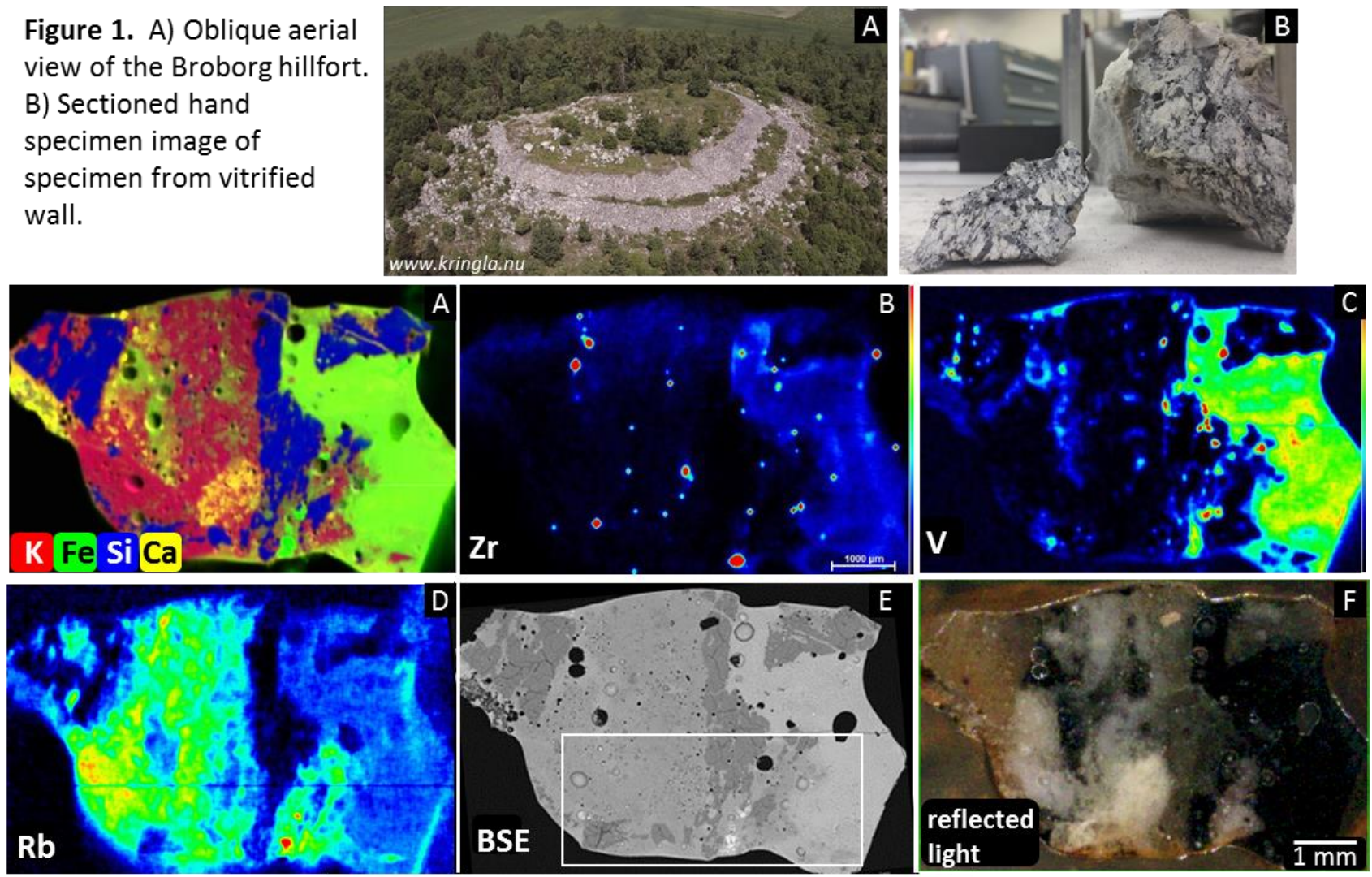

Figure 2. Micro-XRF elemental and electron imagery of vitreous wall fragment. A) Composite x-ray overlay $\left(\mathrm{K} \mathrm{K}_{\alpha}\right.$-red, Fe $\mathrm{K}_{\alpha}$-green, Si $\mathrm{K}_{\alpha}$-blue, $\mathrm{Ca} \mathrm{K}_{\alpha}$-yellow). B-D) single element images in rainbow contrast scale $\mathrm{Zr} \mathrm{K}_{\alpha}$, $\mathrm{Rb} \mathrm{K}_{\alpha}$, and $\mathrm{VK}_{\alpha}$. E) Backscattered electron image (BSE) mosaic, highlighted area enlarge below. F) Reflected light color image.

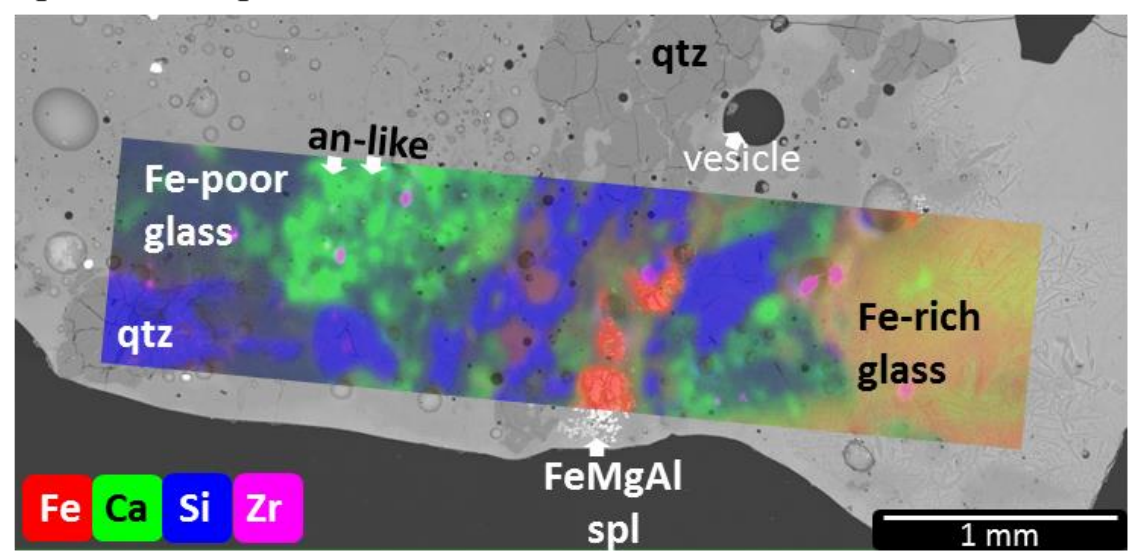

Figure 3. Micro-XRF composite $x$-ray image superimposed on a BSE image showing the boundary between Fe-rich and -poor glasses [Fe $\mathrm{K}_{\alpha}$ red, $\mathrm{Ca} \mathrm{K}_{\alpha}$-green, Si K $\alpha_{\alpha}$-blue, and $\mathrm{Zr} \mathrm{K}_{\alpha}$-majenta; quartz (qtz), anorthite (an), and spinel (spl)].

\begin{tabular}{|c|c|c|c|}
\hline \multirow{23}{*}{$\begin{array}{l}\text { Table 1. Major } \\
\text { and trace } \\
\text { element } \\
\text { analyses of } \\
\text { Fe-rich and - } \\
\text { poor glasses. } \\
\text { Major } \\
\text { elements } \\
\text { determined } \\
\text { by electron } \\
\text { beam X-ray } \\
\text { analysis (wt } \\
\text { \%), and trace } \\
\text { elements } \\
\text { determined } \\
\text { by micro-XRF } \\
\text { (ppm). }\end{array}$} & \multicolumn{2}{|c|}{\begin{tabular}{|c|}
$\begin{array}{c}\text { Fe-rich } \\
\text { glass }\end{array}$ \\
\end{tabular}} & $\begin{array}{c}\begin{array}{c}\text { Fe-poor } \\
\text { glass }\end{array} \\
\end{array}$ \\
\hline & $\mathrm{SiO}_{2}$ & 54.20 & 66.65 \\
\hline & $\mathrm{Al}_{2} \mathrm{O}_{3}$ & 14.69 & 20.12 \\
\hline & $\mathrm{CaO}$ & 6.42 & 0.83 \\
\hline & $\mathrm{MnO}$ & 0.31 & \\
\hline & $\mathrm{FeO}^{*}$ & 11.33 & \\
\hline & $\mathrm{TiO}_{2}$ & 2.26 & \\
\hline & MgO & 3.73 & \\
\hline & $\mathrm{Na}_{2} \mathrm{O}$ & 3.84 & 5.18 \\
\hline & $\mathrm{K}_{2} \mathrm{O}$ & 2.15 & 7.18 \\
\hline & $\mathrm{P}_{2} \mathrm{O}_{5}$ & 0.71 & \\
\hline & Total & 99.64 & 99.95 \\
\hline & v & 279 & \\
\hline & Gr & 27 & \\
\hline & $\mathrm{Fe}$ & & 1962 \\
\hline & Co & 781 & \\
\hline & $\mathrm{Ni}$ & & 20 \\
\hline & $\begin{array}{l}\mathrm{Zn} \\
\text { Ga }\end{array}$ & $\begin{array}{l}362 \\
135\end{array}$ & \\
\hline & $\mathrm{Rb}$ & 152 & 269 \\
\hline & Sr & 972 & 449 \\
\hline & Y & 203 & \\
\hline & $\mathrm{Zr}$ & 1974 & \\
\hline & $\mathrm{Ba}$ & 86 & 1517 \\
\hline
\end{tabular}

